\title{
Når verden skriver teologiens dagsorden - Sydafrika og Palæstina
}

\author{
Professor (mso), ph.d., dr.theol. \\ Peter Lodberg
}

\begin{abstract}
Vatican II represented a fresh start for studies in missiology and ecumenical theology. Especially its call to contextualize and rethink old theological dogmas was well received in many churches in Latin America and Africa that were involved in a process of liberation from old colonial structures. In South Africa the church struggle resulted in the formulation of the Kairos document in 1985. It has since inspired theologians in Palestine/Israel to formulate a Palestinian Kairos document in 2009. In both documents the concepts of reconciliation and restorative justice are used to express interrelated realities. A group of international theologians marked the 500 year of the Reformation by publishing a declaration in January 2017 in Wittenberg, Germany, in line with the two Kairos documents. This shows that in missiology and ecumenical theology new theological inspiration is now coming from the Global South, thereby challenging the Western churches to take a stand in the on-going conflict in Palestine/Israel.
\end{abstract}

Keywords: Vatican II - Kairos South Africa - Kairos Palestine - reconciliation - restorative justice.

Forskning og undervisning i missionsteologi og økumenisk teologi fik en saltvandsindsprøjtning med pave Johannes XXIIIs åbning af Det Andet Vatikanerkoncil i 1962. Med sin anvendelse af udtrykket aggiornamento stillede han koncilet over for den opgave, at det skulle bringe den katolske kirkes liv og lære på omgangshøjde med modernitetens udtryk og udfordringer. Med tøven og stor forsigtighed lykkedes det deltagerne på koncilet i løbet af de næste tre år at fortolke kirkens tradition på en sådan måde, at kirken blev i stand til at tage det moderne liv alvorligt. Ikke mindst den aldrende Johannes XXIII var levende optaget af de mange nye muligheder inden for teknologi og videnskab, som moderniteten bragte med sig. Efter hans død under koncilet i 1963 arbejdede deltagerne videre med at give kirken et moderne udtryk og sprog ud fra en grundlæggende og gennemgående skelnen i den kristne lære mellem det, der har blivende gyldighed i kraft af kirkens tradition, og det, der er tidsbetinget. Hvis Det Første Vatikanerkoncil (1869-1870) havde smækket døren i til den moderne verden, så åbnede Det Andet Vatikanerkoncil (1962-1965) den igen. 
Kirken definerede sig nu ikke i modsætning til moderniteten, men forstod sig som et folk, der er på vandring gennem den moderne verden.

Den katolske kirkes opbrud fra vante teologiske forestillinger og afstandtagen fra at betragte moderniteten som en forfaldshistorie åbnede op for nye økumeniske bestræbelser og en fælles konfessionel refleksion over, hvordan teologien på tværs af de konfessionelle forskelle er udfordret af de spørgsmål, som den moderne verden stiller kirkerne og deres teologier over for. Udfordringerne blev samlet i slagordet om, "at verden skriver kirkens og teologiens dagsorden". Hermed blev der sigtet på den såkaldte empiriske vending i teologien. Udtrykket indeholder en overbevisning om, at teologien skal begynde med en beskrivelse af teologiens og kirkens empiriske kontekst samt anvende indsigter fra især socialvidenskaberne til at analysere, hvordan kirkerne teologisk skal forstå og handle i forhold til de udfordringer, mennesker møder i deres forsøg på at komme til rette med en tilværelse præget af hastig teknologisk og økonomisk udvikling.

Den empiriske vending i teologien kom først og fremmest til at spille en rolle for den række af kontekstuelle teologier, der voksede frem i den katolske kirke i Latinamerika og blandt tidligere protestantiske missionskirker på den sydlige halvkugle. I lande som Brasilien, Argentina, Nicaragua og El Salvador blev befrielsesteologien et samlingspunkt i opgøret med landenes militærjuntaer, og den skulle i løbet af kort tid komme til at tjene som inspirationskilde for især den teologisk funderede kirkekamp i Sydafrika.

I det følgende er det hensigten at vise, hvordan de teologiske erfaringer fra 1980'erne kirkekamp i Sydafrika i dag er begyndt at spille en stadig større rolle for den palæstinensiske teologi i Palæstina/Israel. De palæstinensiske teologer henter ikke længere deres inspiration fra Europa eller Nordamerika, men orienterer sig i deres arbejde med at udarbejde en selvstændig kontekstuel teologi mod sydafrikanske teologer. Udviklingen hænger især sammen med, at de palæstinensiske teologer mener, at de kan lade sig inspirere af, hvordan de sydafrikanske teologer siden 1980'erne har udviklet deres teologiske arbejde i en fortsat dialog med deres empiriske kontekst, og at denne kontekst på mange måder minder om situationen i Palæstina/Israel.

Sydafrika og Palæstina/Israel - kan de sammenlignes?

Teologien er ikke ene om at drage sammenligning mellem Sydafrika og Palæstina/Israel. Diskussionen om sammenligningen mellem Is- 
rael og Sydafrika nåede et foreløbigt højdepunkt i 2006 med tidligere præsident Jimmy Carters bog: Palestine: Peace Not Apartheid. ${ }^{1}$ Hans sammenligning af Israels politik i de besatte områder på Vestbredden med det sydafrikanske apartheidregime blev mødt af stærk modstand af den israelske regering, men blev for mange andre en øjenåbner.

Det interessante er, at sammenligningen mellem Sydafrika og Israel også dukker op i israelsk litteratur. Ari Shavit, der i 2014 udgav sin biografi: My Promised Land er et godt eksempel. ${ }^{2}$ Bogen er senere blevet oversat til dansk. Her opstiller Shavit nutidens dilemma, når han stiller spørgsmålene ${ }^{3}$ :

Vil den jødiske stat opløse de jødiske bosættelser?

Vil de jødiske bosættelser opløse den jødiske stat?

Der er ifølge Shavit fire veje ud af dette dilemma:

Israel som en kriminel stat, der udfører etnisk renselse i de besatte områder;

Israel som en apartheidstat, hvor et israelsk mindretal hersker over et arabisk flertal;

Israel som en binational stat, hvor der er to nationer (jøder og arabere) inden for den samme stat;

Israel som en jødisk-demokratisk stat, der trækker sig til en grænse, der deler landet, det vil sige en to-statsløsning.

Shavit understreger, at de fleste ønsker den fjerde vej med en tostatsløsning, men han frygter en apartheid-stat, hvis den israelske regering annekterer Vestbredden ${ }^{4}$. Dilemmaet handler altså om, hvordan et religiøst bestemt mindretal kan indføre en demokratisk forfatning, der åbner mulighed for, at selv samme mindretal må aflevere den politiske magt til et andet og frygtet flertal.

Modstand mod at sammenligne apartheid i Sydafrika med situationen i Palæstina/Israel kommer fra flere forskellige sider. Blandt de skarpeste kritikkere af en sammenligning er The International Christian Embassy Jerusalem. Ambassaden blev oprettet i 1980 og anerkender genoprettelsen af staten Israel som Guds trofasthed i forhold til overholdelsen af Hans gamle pagt med det jødiske folk. Ifølge organisationens hjemmeside udøver ambassaden blandt andet lobby-virksomhed over for regeringer for at overtale dem til at flytte landenes ambassader

1. Jimmy Carter, Palestine: Peace Not Apartheid (New York: Simon \& Schuster 2006).

2. Ari Shavit, My Promised Land - the triumph and tragedy of Israel (Melbourne/ London: Scribe 2015).

3. Ibid., $398 f$.

4. Ibid., 399. 
fra Tel Aviv til Jerusalem og dermed anerkende Jerusalem som staten Israels evige og udelelige hovedstad. ${ }^{5}$

Én af ambassadens medarbejdere, David Parsons, kritiserede i 2012 afholdelsen af en konference i Betlehem med overskriften Christ at the Checkpoint arrangeret af det evangelikalt orienterede "Bethlehem Bible College". I sin artikel Israel and Christians advarede Parson imod, at evangelikale kristne i USA tager konferencen alvorlig, fordi den er et skalkeskjul for de palæstinensiske befrielsesteologers sædvanlige angreb på Israel. ${ }^{6}$ Samtidig udtrykte han bekymring over for, at en række evangelikale talere på konferencen ville blive misbrugt, når de udviste sympati for den palæstinensiske befolknings lidelser og ønsker om social retfærdighed. Disse talere var ifølge Parsons stort set novicer, når det gælder om at forstå den israelsk-palæstinensiske konflikts komplekse forhold, og de ville derfor være lette ofre for de palæstinensiske teologers anti-israelske propaganda.

Parsons tog især afstand fra, at der på konferencen deltog talere, som anvendte en analogi mellem Israel og apartheid i Sydafrika. Han henviste i den sammenhæng blandt andet til, at konferencen skulle diskutere dokumentet Kairos Palestina, som efter hans mening falbyder både apartheidanalogien og opfordrer til at indføre sanktioner mod Israel, sådan som det også skete mod Sydafrika under apartheid.

\section{Kairos Sydafrika og Kairos Palæstina}

Det er rigtigt set af Parsons, at der er et teologisk slægtsskab mellem de to dokumenter Kairos Sydafrika ${ }^{7}$ og Kairos Palastina ${ }^{8}$. Det palæstinensiske Kairos-dokument blev udgivet i 2009, og forfatterne fra 13 forskellige kirkesamfund med støtte fra deres kirkeledere håber, at deres dokument kan få samme globale gennemslagskraft som det sydafrikanske fra 1985. Det palæstinensiske Kairos-dokument henviser selv til det sydafrikanske Kairos-dokument, der samlede kirkerne i deres modstand mod det hvide mindretalsstyre.

Det sydafrikanske Kairos-dokument afviste to typer af teologi, som det identificerede som henholdsvis statsteologi og kirketeologi. Statsteologien blev beskrevet som den teologi, der sigtede mod at retfærdiggøre apartheid og dermed den samfundsmæssige status quo, uanset

5. Us.icej.org (besøgt 15.05.17).

6. Ibid.

7. "Kairos South Africa", kairossouthafrica.wordpress.com (besøgt 15.05. 17).

8. "Kairos Palestine", www.kairospalestine.ps (besøgt 15.05. 17). 
om denne var præget af racemæssige undertrykkelse og økonomisk udnyttelse af en bestemt befolkningsgruppe.

Kirketeologien legitimerede ikke apartheid-ideologien, men ønskede at forhandle med apartheidstaten. Ifølge Kairos-dokumentet forkyndte denne teologi forsoning uden retfærdighed, tilgivelse uden anger og uacceptable moralske kompromisser. Kirketeologien blev afvist, fordi den anvendte teologiske begreber som forsoning og retfærdighed uden at tage hensyn til den kontekst, hvori de blev benyttet. Den manglede en analyse af apartheidstatens betydning for Sydafrikas politiske, økonomiske og sociale udvikling samt dens konsekvens for landets sorte befolkning. Derfor fremstod kirketeologien ifølge sine kritikere som en ikke bare naiv, men også farlig teologi uden indsigt i de reelle magtforhold i landet og overvejelser over, hvordan de kunne ændres.

Kairos-dokumentet advokerer for den tredje og sidste teologi, som det kalder for profetisk teologi. Det er en teologi, der adresserer de grundlæggende strukturelle årsager bag apartheidstatens ideologi og undertrykkelse. Den profetiske teologi argumenterer for en genopretning af den menneskelige værdighed, frihed fra undertrykkelse og en heling af de dybe sår, som apartheidstaten har påført det sydafrikanske samfund. Det centrale omdrejningspunkt er at skabe et retfærdigt samfund, hvor der kan ske en forsoning på mange af samfundets niveauer.

Den sydafrikanske teolog John de Gruchy har sammenfattet Kairosdokumentets anvendelse af retfærdighed og forsoning i udtrykket restorative justice. ${ }^{9}$ Det er en tilgang, der tager udgangspunkt i ofrenes, overtræderens og samfundets behov ud fra princippet om, at alle har brug for at blive genindsat i den rette relation til hinanden, hvis et ødelagt samfund skal komme på fode igen. Der er således ikke i første omgang fokus på, hvad et abstrakt juridisk begreb eller en bestemt lov kræver af straf i forhold til en bestemt forbrydelse. Derfor indeholder restorative justice også et meget vigtigt hensyn til, hvordan ofret for en forbrydelse kan blive genoprettet i form af menneskelig værdighed, selvrespekt eller ved at få en økonomisk kompensation for det, der er sket. John de Gruchy betoner i denne sammenhæng, at forsoning medfører en fundamental forandring i både personlige og strukturelle magtforhold mellem tidligere fjender. ${ }^{10}$

David Tombs forstår de Gruchys overvejelser om forsoning som restorative justice som et nødvendigt bidrag til det, som er blevet kaldt for

9. John de Gruchy, Reconciliation. Restoring Justice (London: SCM Press 2002).

10. Ibid., 17. 
offentlig teologi (public theology). ${ }^{11}$ Det centrale er her ifølge Tombs, at 'forsoning' forstået som restorative justice med inspiration fra især Sandheds- og Forsoningskommissionen i Sydafrika i stadig større udstrækning bliver anvendt uden for teologien i andre discipliner og i det offentlige rum. Forsoning opfattes i disse sammenhænge som et sekulært begreb til at beskrive en vigtig udfordring i et post-konflikt samfund, hvor borgerne skal til at leve sammen igen samtidig med, at de bærer rundt på erindringen om tidligere tiders vold og modsætninger.

Tombs peger i den forbindelse på, at forsoning i den ikke-teologiske litteratur bliver forstået som en del af en endnu ikke afsluttet fredsopbygningsproces. Det processuelle i opfattelsen af, hvad forsoning er, bidrager samtidig til at betone, at forsoning har både en dyb personlig side og en strukturel side i forhold til heling af lokalsamfund. Under alle omstændigheder har den sekulære brug af begrebet om forsoning bidraget til, at det har genvundet sin offentlige dimension efter at det i teologihistorien er blevet privatiseret som kun omhandlende menneskets relation til Gud. Tombs anerkender, at kirkerne gennem tiden som regel har betonet forsoningens sakramentale og dogmatiske dimension, men han kritiserer, at deres teologi har overset den dimension, der hører sammen med forsoningens kollektive betydning og dens sociale budskab. Det er først fra midten af 1990'erne, at kristen teologi har haft noget at sige i forhold til spørgsmålet om social forsoning. ${ }^{12}$

Set i forlængelse heraf er det ikke overraskende, at det palæstinensiske Kairos-dokument anvender begrebet om restorative justice i betydningen social forsoning. Det betoner således, at der er en vilje hos mange palæstinensere til at komme ud over fortidens nag og være parate til forsoning, når retfærdighed er genoprettet. ${ }^{13}$ Det hedder også, at målet er at befri både israelere og palæstinensere fra de forskellige israelske regeringers ekstreme positioner, så begge folk kan leve forsonet med retfærdighed. ${ }^{14}$

\section{Den bibelske baggrund}

Restorative justice som "forsoning med retfærdighed" henter sit teologiske indhold fra både Det Gamle og Det Nye Testamente. Retfær-

11. David Tombs,"Public Theology and Reconciliation", A Companion to Public Theology, red. Sebastian Kim \& Katie Day (Leiden: Brill 2017), 119-149.

12. Ibid., 119.

13. "Kairos Palestine", Jerusalem 2009, pkt. 3.3.4

14. Ibid. pkt. 4.2.6. 
dighed bliver i Det Gamle Testamente beskrevet som både forensisk retfærdighed (mishpat) og retfærdighed i kraft af et offer (tsedaqah). Det Nye Testamentes begreb om retfærdighed (dikaiosynē) indeholder ifølge professor i systematisk teologi ved Stellenbosch Universitet Nico Koopman begge betydninger. ${ }^{15}$ Det er i Det Gamle Testamente et etisk begreb, der tager sigte på at beskytte retten til det liv, som ethvert menneske har fået som skabt. Guds retfærdighed henviser til at beskytte den sårbare, hvad enten det drejer sig som enken, den faderløse eller flygtningen. Den kan blive til en dom, når Gud dømmer den, som ikke levede op til sit ansvar, men manipulerede og udnyttede andre mennesker til sin egen fordel. Hvis mishpat knytter sig til retten, så knytter tsedaqah sig til den rette relation. Guds lov er en gave, der sigter på at etablere de forhold, hvorved de rette relationer bliver etableret og opretholdt. Det Gamle og Det Nye Testamente bevidner, at det er nødvendigt at bringe et offer for at genoprette brudte relationer og holde dem vedlige.

Den palæstinensiske teolog Naim Ateek betoner, at Gud gennem Jesu død og opstandelse erklærer det menneske, der er skabt i Guds billede, for genindsat i den rette relation til Gud og medmennesket. ${ }^{16}$ Det menneske, der er gjort retfærdig ved Guds nåde, er nu sat fri til at deltage i en fælles søgen mod retfærdighed, der består i at genoprette brudte relationer. Med professor Christopher Marshall kan det derfor understreges, at retfærdiggørelse ved tro er et udtryk for genoprettende retfærdighed (restorative justice). ${ }^{17}$

Den genoprettende retfærdighed er andet og mere end en retfærdighed, der søger hævn. Den søger tværtimod at hele og genoprette den brudte relation mellem lovovertræder og offer. Her knytter forståelsen af den genoprettende retfærdighed sig til begrebet om forsoning. Det optræder som det græske substantiv $\kappa \alpha \tau \alpha \lambda \lambda \alpha \gamma \eta$, 4 gange hos Paulus som et udtryk for Guds frelsende handling i Kristus (Rom 5,11; 11,15; 2 Kor $5,18,19)$. Verbet er $\kappa \alpha \tau \alpha \lambda \lambda \alpha \dot{\sigma} \sigma \sigma \omega$, der betyder "at gøre en forskel", "at ændre" eller "at udveksle". Indholdsmæssigt henviser substantivet således til 'transformation' eller 'reformation' i betydning af en radikal forandring. Det skal forstås i sammenhæng med en genopretning af noget allerede brudt, sådan som det fx fremgår af 2 Kor 5,17-20:

15. Nico Koopman, "Public Theology in the Context of Nationalist Ideologies: A South African Example", A Companion to Public Theology, red. Sebastian Kim \& Katie Day (Leiden: Brill 2017), 150-163.

16. Naim Ateek, Justice and Only Justice: A Palestinian Theology of Liberation (New York: Orbis 1989), 142ff.

17. Christopher Marshall, Beyond Retribution: A New Testament Vision for Justice, Crime and Punishment (Grand Rapids: Eerdmans 2001). Marshall varetager et professorat i restorative justice ved det newzealandske Victoria Universitet. 
Altså: Er nogen i Kristus, er han en ny skabning. Det gamle er forbi, se, noget nyt er blevet til! Men alt dette skyldes Gud, som forsonede ( $\left.\kappa \tau \tau \alpha \lambda \lambda \alpha^{\prime} \xi \alpha \nu \tau o \zeta\right)$ os med sig selv ved Kristus og gav os forsoningens ( $\alpha \tau \alpha \lambda \lambda \alpha \gamma \hat{\eta} \varsigma)$ tjeneste, for det var Gud, der i Kristus forsonede ( $\kappa \tau \tau \alpha \lambda \lambda \alpha \dot{\sigma} \sigma \omega \nu)$ verden med sig selv og ikke tilregnede dem deres overtrædelser, men betroede os ordet om forsoningen ( $\kappa \alpha \tau \alpha \lambda \lambda \alpha \gamma \eta \hat{)})$. Så er vi altså udsendinge i Kristi sted, idet Gud så at sige formaner gennem os. Vi beder på Kristi vegne: Lad jer forlige ( $\left.\alpha \tau \alpha \lambda \lambda \alpha^{\prime} \gamma \eta \tau \epsilon\right)$ med Gud!

Paulus taler her om en radikal forandring af mennesket i form af en nyskabelse. Den er samtidig en genoprettelse af den brudte forbindelse mellem Gud og mennesket med udgangspunkt i Guds suveræne handling over for sin skabning. Der er således tale om en nyskabelse af alle de brudte relationer, som er et resultat af skabningens synd. I den sammenhæng er det interessant at bemærke, at ordet synd på dansk knytter sig til det gamle ord for sund i betydningen af det, der adskiller, jf. Øresund, der adskiller to lande fra hinanden.

Syndens afstand mellem Gud og mennesker samt mellem mennesker indbyrdes bliver ophævet i kraft af Guds forsonende handling i Jesus Kristus. Omdrejningspunktet er korsbegivenheden, sådan som det fremgår af Kol 1,20, hvor Paulus understreger, at Gud nu har fuldt ud forsonet ( $\left.\dot{\alpha} \pi \circ \kappa \alpha \tau \alpha \lambda \lambda \alpha_{\alpha} \xi \alpha \iota\right)$ sig med de, der var fremmede og fjendske af sind, ved Kristi legemlige død. $\dot{\pi} \pi о \kappa \alpha \tau \alpha \lambda \lambda \alpha \dot{\alpha} \sigma \sigma \omega$ bruges også i Ef. 2,15-16: "Han satte loven med dens bud og bestemmelser ud af kraft for i sig at skabe ét nyt menneske og således stifte fred og for ved korset at forsone ( $\left.\alpha \pi \circ \alpha \alpha \tau \alpha \lambda \alpha^{\prime} \xi \eta \eta \eta\right)$ dem begge fuldt ud med Gud i ét legeme, og derved dræbte han fjendskabet".

Det er et tilbagevendende tema i soteriologien, hvordan korset bevirker forsoning, og hvordan begrebet om forsoning hører sammen med andre soteriologiske begreber som $\mathrm{fx}$ forløsning eller retfærdigg ørelse samt frelse og forligelse. Hvert af disse begreber har deres styrke og svaghed, men ikke desto mindre er det tydeligt, at forsoningen ifølge en paulinsk soteriologi sker gennem korset, og at initiativet til at erstatte fjendskab og afstand med samhørighed og enhed kommer fra Gud - og ikke fra mennesket. Mennesket er kaldet tilbage til at høre til hos Gud og hos hinanden.

Når den palæstinensiske teologi hos fx Naim Ateek betoner, at talen om forsoning involverer en genoprettende retfærdighed, så er det også for at betone den "dyre nåde", det vil sige den nødvendige forandring, der knytter sig til anger, bod og ændring af livsstil. Med inspiration fra Dietrich Bonhoeffers bog Nachfolge (1937) understreger han, at ethvert menneske er kaldet til at tage del i forsoningen og være et forsoningens instrument, men i det kald lyder også kravet om at gøre 
op med den sociale uretfærdighed, som forhindrer, at mennesker kan leve et liv i overensstemmelse med Skaberens hensigt, det vil sige et liv i hele dets fylde. En sådan situation foreligger ifølge Kairos Palastinadokumentets forfattere på Vestbredden og i Gaza.

Baggrunden for anvendelsen af restorative justice som både individuel og social forsoning hænger således sammen med den analyse af palæstinensernes situation, som indleder det palæstinensiske Kairosdokument. Her bliver det beskrevet, hvordan Muren rundt om Vestbredden, som er bygget på palæstinensisk område, har splittet befolkningen og gjort byer og landsbyer til fængsler adskilt fra hinanden. Dokumentet peger også på de daglige ydmygelser ved de israelske checkpoints, indskrænkning af religionsfriheden og anlæggelse af bosættelser som en del af den palæstinensiske virkelighed, der har til formål at forhindre den palæstinensiske befolkning $\mathrm{i}$ at blive boende.

Set i forhold til hovedindholdet i den palæstinensiske teologi, der er vokset frem siden 1967, skærper Kairos Palastina den teologiske analyse og sprogbrug på ét afgørende punkt. ${ }^{18}$ Den israelske besættelse af Palæstina betegnes som en synd imod Gud og imod menneskeheden, fordi besættelsen fratager palæstinenserne deres grundlæggende menneskerettigheder, givet af Gud. Den ødelægger gudsbilledet i den israeler, der er blevet besætter, på samme måde som den ødelægger gudsbilledet i de palæstinensere, der lever under besættelsen. ${ }^{19}$

Ved at kalde besættelsen for en synd, nærmer dokumentet sig det teologiske synspunkt, som i den sydafrikanske kirkekamp kom til udtryk i anvendelsen af begrebet om status confessionis. ${ }^{20}$ Sydafrikanske teologer som Allan Boesak, John de Gruchy og Beyers Naudé forstod det i forlængelse af Dietrich Bonhoeffer. Han betonede, at der foreligger en status confessionis, når der er for megen og for lidt orden og ret $i$ et samfund. Det første er tilfældet, hvis staten griber ind i kirkens egne anliggende, og det andet opstår, når staten ikke sørger for at opretholde orden og ret i et samfund ${ }^{21}$. Bag Bonhoeffers opfattelse ligger tanken om, at staten og kirken skal minde hinanden om deres indbyrdes grænse og ansvar. Der er således ikke tale om, at kirken blindt skal adlyde statens krav og politik, men at de to regimenter har et fælles ansvar for, at der er orden og ret i et samfund.

Det er ikke muligt for de palæstinensiske teologer at anvende et begreb om status confessionis, fordi det hører hjemme i en reformato-

18. Se min analyse af palæstinensisk teologis udvikling i Peter Lodberg, Tro og magt $i$ Det Hellige Land. Palestinensisk teologi og kirke i et transformationssamfund efter 1967 (København: Aros 2010).

19. "Kairos Palestine", pkt. 2.5.

20. Peter Lodberg, Apartheid og de lutherske kirker (Aarhus: Anis 1988).

21. Ibid., 80. 
risk teologisk kontekst og er ukendt i ortodoks eller katolsk teologi. Det har været nødvendigt for forfatterne til Kairos Palestina at finde et udtryk, der går på tværs af de forskellige konfessionelle traditioner. Her er valget faldet på begrebet om synd. Det understreger, at det hører til troens indhold og bekendelse at tage afstand fra den israelske besættelse. Under normale omstændigheder kan kristne have forskellige holdninger til politiske og samfundsmæssige spørgsmål, men anvendelsen af status confessionis markerer, at tiden nu er inde til at fordømme besættelsen og dens teologiske legitimering som en hæretisk tilsidesættelse af evangeliets indhold og kirkens væsen. Der er derfor brug for på ny at bekende den kristne tro i lyset af det overgreb mod den værdighed, der er nedlagt i både israeler og palæstinenser som mennesker skabt i Guds billede. Med til dette synspunkt hører også opfattelsen af, at både israelere og palæstinenser lider under besættelsen, og at de derfor er bundet sammen af en konflikt, der kun kan løses, når begge er sat fri i kraft af en ophævelse af besættelsen.

\section{Landløfter}

Anvendelsen af begrebet synd signalerer således også et teologisk opgør med de teologiske synspunkter, der legitimerer den israelske besættelse af Palæstina. Det drejer sig om en teologi, der forstår landløfterne i Biblen som et politisk program og ikke som et udtryk for Guds tilsagn om frelse og fuldendelse af Guds rige. I forlængelse heraf afviser Kairos Palestina enhver form for teologi, der legitimerer eller støtter synspunkter, der baserer sig på uretfærdighed påført en person af en anden, eller et folk af et andet. Det forvrænger religion til en menneskelig ideologi og fratager Guds ord dets hellighed, universalitet og sandhed.

Især kritikken af at opfatte de bibelske landløfter som et politisk program, der er blevet realiseret i form af oprettelsen af staten Israel, retter sig mod den såkaldte kristne zionisme. Det er et teologisk synspunkt, der ifølge de amerikanske teologer Rosemary Radford Ruether og Herman J. Ruether har rødder tilbage i puritanske og evangelikale kredse i England. ${ }^{22}$ Det blev fremført af den engelske udenrigsminister Lord Balfour, da han i 1922 over for medlemmerne af det britiske parlaments Overhus forklarede, hvorfor han aftenen før, at general Allenby holdt sit indtog i Jerusalem i 1917, udsendte en erklæring,

22. Rosemary Radford Ruether and Herman J. Ruether, The Wrath of Jonah. The Crisis of Religious Nationalism in the Israeli-Palestinian Conflict (Minneapolis: Fortress Press 2002). 
hvor han lovede, at jøderne skulle få deres eget nationale hjem i Palestina.

Den såkaldte Balfour-erklæring kom til at spille en afgørende rolle for FNs vedtagelse af oprettelse af staten Israel i 1947 og den senere realisering året efter. Her spillede også den religiøse identifikation blandt mange amerikanske jøder og kristne med staten Israel en vigtig rolle. Mange amerikanske kristne var og er fortsat enige i synspunktet om, at Gud har givet Palæstina til det jødiske folk som en permanent og eksklusiv gave. Bagsiden af denne zionistiske opfattelse af de bibelske landløfter er, at den fratager palæstinenserne enhver ret eller mulighed for at kunne eje jord i det land, hvor de har boet i mange generationer.

Den kristne zionisme bliver ifølge Radford Ruether understøttet af en såkaldt kristen post-Holocaust teologi, som betoner, at kristnes ansvarlighed for uhyrlighederne i forbindelse med Holocaust kræver anger i form af en ubegrænset støtte til Israel. ${ }^{23}$ Det er en form for anger, der indeholder dels en form for kompensation for de kristnes synd mod jøderne, dels en nødvendig beskyttelse af jøderne mod en gentagelse af Holocaust. Kritik af Israel bliver derfor betragtet både som anti-semitisme og en trussel mod staten Israels eksistens.

Kairos Palastinas kritik af, at de bibelske landløfter bliver brugt til at retfærdiggøre den israelske statsdannelse og efterfølgende besættelse af Palæstina omfatter både den kristne zionisme og post-Holocaust teologien. Set i lyset af det sydafrikanske Kairos-dokumentet kommer Kairos Palastina tæt på at betragte den kristne zionisme som statsteologi og post-Holocaust teologien som kirketeologi, mens forfatterne repræsenterer det, som i 1985 blev kaldt profetisk teologi.

Den profetiske teologi i Kairos Palastina er karakteriseret ved, at den er økumenisk og inter-religiøs. Den respekterer, at den kristne kirkes historie i Palæstina er præget af mange og dybe teologiske, historiske og politiske splittelser, men den accepterer ikke, at de fortsat skal have lov til at spille den dominerende rolle, når den kristne kirkes overlevelse står på spil. Den er også inter-religiøs i sit forsøg på at etablere en samtale og et samarbejde mellem kristne, jøder og muslimer, fordi de har et fælles ansvar for retfærdighed og forsoning i det ene land Palæstina/Israel.

Kairos Palastina er ikke imod staten Israels eksistens, men imod israelsk besættelse. Vejen til forsoning må gå gennem anvendelse af fredelige ikke-voldshandlinger. Hertil hører civil ulydighed, sådan

23. Rosemary Radford Ruether, "The Quest for Peace with Justice in the Middle East: Christian Zionist and Palestinian Theologies", Theologies of Liberation in Palestine-Israel. Indigenous, Contextual, and Postcolonial Perspectives, red. Nur Masalha \& Lisa Isherwood (Eugene, Oregon: Pickwick Publications 2014), 127-140. 
som vi så det i den amerikanske borgerrettighedsbevægelse og den sydafrikanske kirkekamp. Det er en forsoningsproces, der skal forsone partikularisme og universalisme samt religiøse og etniske identiteter. Den profetiske teologi afviser eksklusiviteten i form af, at ét folk skulle være udvalgt på bekostning af andre folk, eller at én stat har en universel ret til at undertrykke et andet folks legitime ønske om også at kunne leve i sin egen nationalstat. Idealet er at søge frem mod en situation, hvor der kan opnås en gensidig respekt mellem folk i Palæstina/Israel. Forsoning er aldrig let, men der er intet bedre alternativ til at gøre forsøget ifølge Kairos Palastina. Alternativet er, at undertrykkelse og usikkerhed kun vil tage til i styrke.

Initiativtagerne til Kairos Palæstina arbejder videre, og i de seneste år har de haft en omfattende rejseaktivitet for at orientere kirkelige og teologiske miljøer uden for Mellemøsten om det, som kan kaldes en profetisk palæstinensisk teologi.

\section{At radikalisere den reformatoriske arv}

Senest har en gruppe internationale teologer og kirkefolk således arbejdet videre med de teologiske principper i Kairos-dokumenterne. I anledning af reformationsjubilæet udsendte de i januar 2017 en erklæring fra et møde i Wittenberg, hvis titel er: Kun retfardighed. At radikalisere reformationen $i$ lyset af dagens systemiske krise. ${ }^{24}$

Erklæringen er udformet som en bekendelse, der bringer mindelser om Barmen-erklæringen fra 1934, som udtrykte en gruppe protestantiske teologers og kirkefolks protest mod naziregimet, der var kommet til magten året forinden. Barmen-erklæringen inspirerede under den sydafrikanske kirkekamp til formuleringer af nye bekendelser, der forholdt sig til den kirkelige og politiske situation i landet. Fælles for denne tradition er inspirationen fra Bonhoeffer, der sammenfattede sin teologiske holdning til, hvordan en teologisk og politisk krisesituation skal opfattes, i udtrykket: Handlingen er den første bekendelse. ${ }^{25}$

Det interessante og nye er, at deltagerne i Wittenberg formulerer sig bekendelsesteologisk på en tilsvarende måde i forhold til Palæstina/ Israel. Den centrale del af teksten lyder således i min oversættelse:

24. Originalteksten Radicalizing Reformation - Wittenberg Declaration, January 10, 2017 fremgår af www.radicalizing-reformation.com (besøgt d. 22. juni 2017).

25. Dietrich Bonhoeffer, Das Wesen der Kirche, DBW 11 (Gütersloh: Chr. Kaiser/ Gütersloher Verlagshaus 1994 [1932]), 239-303. 


\section{Interreligiøs solidaritet for retfærdighed i Palæstina/Israel}

Gud har kaldet os til at være barmhjertighedens kar - ikke kun blandt jøder, men også blandt hedninger (Rom 9,24).

Vi tror med apostlen Paulus, at i Messias Jesus er de etniske, religiøse, klassemæssige og kønsmæssige samt de systemiske magtstrukturer blevet overvundet ( $\mathrm{Gal} \mathrm{3,28).} \mathrm{Vi} \mathrm{tror,} \mathrm{at} \mathrm{den} \mathrm{post-konstantinske} \mathrm{anti-jødedom}$ i kristendommen, og især i Luthers hadefulde og ondskabsfulde skrifter mod jøderne, som blev brugt af nazismen til at myrde millioner af mennesker, var en forbrydelse mod menneskeheden. Men vi er overbeviste om, at kristne og kirker ikke kan bøde for denne forbrydelse ved at undlade at tage stilling til den uacceptable overtrædelse af menneskerettigheder og international lov, som staten Israel gør sig skyld i, når den koloniserer det historiske Palæstina og udfører etnisk renselse af det palæstinensiske folk uden for de af FN godkendte grænser.

Vi bekender, at vi er en del af en historie præget af kristen anti-jødedom og de kristne kirkers tavshed over for den ubærlige undertrykkelse af palæstinenserne.

$\mathrm{Vi}$ afviser alle former for anti-semitisme og samtidig alle teologier, der støtter eller retfærdiggør den fortsatte udnyttelse og undertrykkelse af palæstinenserne. Vi afviser ligeledes den kirketeologi, der ligger under kirkernes tavshed, når de prædiker forsoning og dialog uden retfærdighed.

Vi opfordrer kirkerne, herunder Den Evangeliske Kirke i Tyskland (EKD) til at afvise Luthers skrifter mod jøderne og samtidigt klart og offentligt tage parti for vore søsterkirker og mennesker af tro i Palæstina/ Israel samt over hele verden udfordre deres regeringer til at sætte betingelser for økonomisk støtte og samarbejde med staten Israel for at befri Palæstina i overensstemmelse med FN-resolutioner og fundamentale menneskerettighedsprincipper. Det vil også befri Israel fra at være en undertrykker og åbne en ny vej for at kunne være fælles om Jerusalem. Vi opfordrer til, at alle følger det eksempel, som mange kirker i USA, Sydafrika og Skotland sætter, når de støtter ikke-voldelige midler som boykot, tilbagetrækning af investeringer og brug af sanktioner (BDS), sådan som det palæstinensiske civilsamfund opfordrede til i 2005. Opfordringen blev bekræftet i 2009 af kirkerne i regionen i det palæstinensiske Kairos- dokument. Den skal gentages i dag efter 50 år med illegal kolonisering af Vestbredden og den umenneskelige blokade af Gaza. Vi opfordrer også til at sætte en klar standard for alle kirke-støttede rejser til Palæstina/Israel.

Vi forpligter os til at bede for fred og retfærdighed i Palæstina/Israel og at leve op til disse teologiske og politiske forpligtelser på alle niveauer. Det omfatter også udfordringen med at blive bekendende kirke, der er engageret i ikke-voldelig civil ulydighed, at byde flygtninge fra regionen 
velkommen og at arbejde sammen med folk fra alle trosretninger for at udvikle en kultur, hvor enhver kan leve det liv, de har krav på.

Erklæringen fra Wittenberg nævner ikke direkte apartheid, men henviser indirekte til det sydafrikanske Kairos-dokument, når det kritiserer kirketeologien for at forkynde forsoning uden retfærdighed. Koloniseringen henviser til den ændring af infrastrukturen på Vestbredden, der finder sted i disse år, og som adskiller israeler fra palæstinenser samt palæstinenser fra palæstinenser. Anlæggelse af særlige bosætterveje, inddragelse af jord, oprettelse af check-points, bygning af Mur og bosættelser, forskelle i adgang til vand, begrænsning af bevægelsesfriheden og muligheden for at tage til gudstjeneste i Gravkirken koloniserer palæstinensisk område og ejendom. Udviklingen vidner om adskilt udvikling for henholdsvis israelere og palæstinensere.

\section{Til sidst}

Wittenberg-erklæringen er et eksempel på, at det teologiske arbejde, der har foregået i Palæstina/Israel inden for de sidste tyve år med at beskrive og analysere den politiske og sociale kontekst teologisk, nyder voksende international bevågenhed. Men det er ikke længere europæisk eller nordamerikansk teologi, der er inspirationskilde for fx palæstinensisk teologi. Inspirationen kommer i dag fra især Sydafrika, og de europæiske og nordamerikanske kirker bliver derigennem udfordret til at tage stilling til, om de repræsenterer en zionistisk kristen statsteologi, en post-holocaustkirketeologi eller en profetisk teologi. Om Vestens kirker vil tage imod udfordringen vil fremtiden vise. 